\title{
Pathogenesis of Hepatitis B Virus Infection
}

\author{
Francis V. Chisari, Masanori Isogawa, and Stefan F. Wieland \\ Department of Immunology and Microbial Science The Scripps Research Institute La Jolla, CA \\ 92037 USA
}

\section{Abstract}

The adaptive immune response is thought to be responsible for viral clearance and disease pathogenesis during hepatitis B virus infection. It is generally acknowledged that the humoral antibody response contributes to the clearance of circulating virus particles and the prevention of viral spread within the host while the cellular immune response eliminates infected cells. The $\mathrm{T}$ cell response to the hepatitis B virus (HBV) is vigorous, polyclonal and multispecific in acutely infected patients who successfully clear the virus and relatively weak and narrowly focussed in chronically infected patients, suggesting that clearance of $\mathrm{HBV}$ is $\mathrm{T}$ cell dependent.

The pathogenetic and antiviral potential of the cytotoxic T lymphocyte (CTL) response to HBV has been proven by the induction of a severe necroinflammatory liver disease following the adoptive transfer of HBsAg specific CTL into HBV transgenic mice. Remarkably, the CTLs also purge HBV replicative intermediates from the liver by secreting type 1 inflammatory cytokines thereby limiting virus spread to uninfected cells and reducing the degree of immunopathology required to terminate the infection.

Persistent HBV infection is characterized by a weak adaptive immune response, thought to be due to inefficient $\mathrm{CD} 4+\mathrm{T}$ cell priming early in the infection and subsequent development of a quantitatively and qualitatively ineffective CD8+ T cell response. Other factors that could contribute to viral persistence are immunological tolerance, mutational epitope inactivation, $\mathrm{T}$ cell receptor antagonism, incomplete down-regulation of viral replication and infection of immunologically privileged tissues. However, these pathways become apparent only in the setting of an ineffective immune response which is, therefore, the fundamental underlying cause. Persistent infection is characterized by chronic liver cell injury, regeneration, inflammation, widespread DNA damage, and insertional deregulation of cellular growth control genes which, collectively, lead to cirrhosis of the liver and hepatocellular carcinoma.

\section{Keywords}

cytotoxic T cells; liver cirrhosis; hepatocellular carcinoma; innate immune response; adaptive immune response; chronic infection

Publisher's Disclaimer: This is a PDF file of an unedited manuscript that has been accepted for publication. As a service to our customers we are providing this early version of the manuscript. The manuscript will undergo copyediting, typesetting, and review of the resulting proof before it is published in its final citable form. Please note that during the production process errors may be discovered which could affect the content, and all legal disclaimers that apply to the journal pertain. 


\section{Introduction}

Viral hepatitis is a necroinflammatory liver disease of variable severity. Persistent infection by HBV is often associated with chronic liver disease that can lead to the development of cirrhosis and hepatocellular carcinoma (HCC). Many studies suggest that HBV is not directly cytopathic for the infected hepatocyte [1-3]. For example, during the early phase of HBV infection in chimpanzees (i.e., before virus-specific T cells enter the liver), $100 \%$ of the hepatocytes may be infected without histological or biochemical evidence of liver disease [4,5]. Furthermore, when cellular immune responses are deficient or pharmacologically suppressed, HBV can replicate at high levels in the liver of patients [and in immunologically tolerant HBV transgenic mice [3]] in the absence of cytological abnormalities or inflammation [6-8].

Viral clearance and disease pathogenesis are largely mediated by the adaptive immune response in HBV infection [2]. For HBV to persist it must either not induce a response or it must overwhelm, evade or counteract it. Interestingly, HBV "evades" the innate immune response by simply not inducing it, acting as a stealth virus in this regard [9]. On the other hand, viral persistence is characterized by a state of relative hyporesponsiveness of HBVspecific $\mathrm{T}$ cells [6,10-13]. Several viral proteins have been shown to regulate the adaptive immune response to HBV (as described below) suggesting that HBV may employ active evasion strategies targeting the adaptive immune response [1,5,6,10,13-19]. Indeed, it has been shown that antiviral treatment can overcome CD8+ T cell hyporesponsiveness in chronic HBV infection, suggesting that the T cells are present in these subjects but suppressed [20]. Importantly, a recent study suggests induction of an effective HBV specific $\mathrm{CD} 8+\mathrm{T}$ cell response is dependent on early $\mathrm{CD} 4+\mathrm{T}$ cell priming which might be regulated by the size of the viral inoculum [21].

\section{Characteristics of the Immune Response to HBV}

\section{Absence of an Innate Response by Infected Cells}

Virus replication often results in the induction of an innate immune response which is heralded by rapid induction of IFN $\alpha / \beta$ by the infected cell [22]. Production of IFN $\alpha / \beta$ induces the transcriptional expression of a large number of interferon inducible genes (ISGs) which in turn exert a variety of intracellular antiviral mechanisms that have the potential to minimize pathogenetic processes by limiting viral production and spread [22,23].

Surprisingly, as shown in Figure 1a, intrahepatic gene expression profiling in acutely HBV infected chimpanzees revealed that HBV acts like a stealth virus early after infection since it does not induce any cellular gene expression including ISGs as it spreads through the liver $[9,23]$. This is in stark contrast to the induction of many ISGs during the spread of hepatitis $\mathrm{C}$ virus (HCV) infection in chimpanzees, as shown in Figure 1b, suggesting that, unlike $\mathrm{HBV}, \mathrm{HCV}$ is highly visible to the innate immune system [23-25]. The relative invisibility of HBV to the innate sensing machinery of the cells likely reflects its replication strategy, which retains the transcriptional template in the nucleus, involves the production of capped and polyadenylated viral mRNAs that resemble the structure of normal cellular transcripts, and sequesters its replicating genome within viral capsid particles in the cytoplasm $[8,26,27]$. Thus, the typical widespread expansion of HBV in the liver may reflect the absence of IFN $\alpha / \beta$ production to which the virus is exquisitely sensitive as has been shown in HBV transgenic mice $[28,29]$.

\section{The Adoptive Immune Response}

The Antibody Response-The antibody response to the HBV envelope antigens is a T cell-dependent process [30]. Because these anti-envelope antibodies are readily detectable in 
patients who clear the virus and recover from acute hepatitis, and they are usually undetectable in patients with chronic HBV infection, they are thought to play a critical role in viral clearance by complexing with free viral particles and removing them from circulation or by preventing their attachment and uptake by hepatocytes. This notion is supported by the observation that chimpanzees that resolved a previous infection are completely protected from rechallenge [31]. The appearance of neutralizing antibodies, however, occurs relatively late after HBV exposure and, thus, it is unlikely to contribute to the early phase of viral clearance during acute infection. Instead they probably prevent viral spread from rare cells that remain infected after resolution of $\mathrm{HBV}$ infection.

The CD4 T Cell Response-The peripheral blood CD4 T cell response to HBV is vigorous, and multispecific in patients with acute hepatitis who ultimately clear the virus, while it is relatively weak in persistently infected patients with chronic hepatitis [32]. Although the association between a strong CD4 T cell response, acute hepatitis, and viral clearance suggests that a relationship exists between these events [30,32,33] , CD4 T cell depletion at the peak of HBV infection had no effect on viral clearance and liver disease in infected chimpanzees [5], suggesting that CD4 $\mathrm{T}$ cells do not directly participate in viral clearance and tissue damage. As we will discuss in more detail later in this review CD4 T cells probably contribute indirectly to the control of HBV infection by facilitating the induction and maintenance of the virus-specific (B cell) and CD8 T cell response.

The CD8 T Cell Response-The HBV specific CD8 T cell response plays a fundamental role in viral clearance and the pathogenesis of liver disease. A vigorous polyclonal CD8 T cell response is readily detectable in the peripheral blood of patients with acute hepatitis who ultimately clear HBV. In contrast, the peripheral blood T cell response in chronically infected patients is weak and narrowly focused $[11,13,15,30]$. The livers of these patients contain virus-specific $\mathrm{T}$ cells that likely contribute to disease pathogenesis, but for functional and/or quantitative reasons are unable to clear the infection. Interestingly, a recent study that examined a relationship between the number of intrahepatic HBV specific CD8 T cells, extent of liver disease, and levels of HBV replication in chronically infected patients indicated that inhibition of virus replication could be independent of liver damage, and that the functionality of $\mathrm{HBV}$-specific CD8 T cells was more important than the number of $\mathrm{T}$ cells to control HBV replication [34]. Experiments in chimpanzees have shown that the viral clearance and the onset of liver disease coincide with the accumulation of virus-specific CD8 T cells and the induction of IFN $\gamma$ and IFN $\gamma$-inducible genes in the liver $[4,5]$.

Importantly, depletion of CD8 T cells at the peak of viremia delays viral clearance and onset of viral hepatitis until the $\mathrm{T}$ cells return, proving that the viral clearance and liver disease are mediated by virus specific CD8 T cells [5].

\section{Mechanisms of HBV Clearance}

It is widely believed that the CTL response clears viral infections by killing infected cells. CTL killing is an inefficient process, however, requiring direct physical contact between the CTLs and the infected cells. Thus, it may not be possible for CTLs to kill all HBV infected cells if the CTLs are greatly outnumbered as occurs during HBV infections in which as many as $10^{11}$ hepatocytes can be infected $[4,5,21]$. Thus, although the liver disease in HBV infection is clearly due to the cytopathic activity of the CTL response, viral clearance may require more efficient CTL functions than killing. Important insights into the pathogenetic and noncytopathic antiviral functions of the CTL response have come from studies in HBV transgenic mice that develop an acute necroinflammatory liver disease after adoptive transfer of HBsAg specific CTL clones [35-37]. In that model (Figure 2), the CTLs rapidly enter the liver and recognize viral antigen which triggers two events: (a) apoptosis of the hepatocytes that are physically engaged by the CTLs, and (b) secretion of interferon gamma 
(IFN $\gamma$ ) which noncytopathically inhibits HBV gene expression and replication in the rest of the hepatocytes $[37,38]$ by preventing the assembly of HBV RNA-containing capsids in the cytoplasm [29,39] in a proteasome-[40] and kinase-dependent [41] process. During this remarkable process, the viral nucleocapsids disappear from the cytoplasm of the hepatocytes $[29,37]$ and the viral RNAs are destabilized by a SSB/La-dependent mechanism in the nucleus [30,42-44], yet the hepatocytes remain perfectly healthy [30,38]. Antibody blocking and knockout experiments in the HBV transgenic mouse model further demonstrated that the cytopathic and antiviral functions of CTLs are completely independent of each other [37]. These results suggest that a strong intrahepatic CTL response to HBV can suppress viral gene expression and replication noncytopathically.

Interestingly, it has been shown that HBV replication is also suppressed by the antiviral effects of interferon alpha/beta [28,29,45]. Indeed, in the transgenic mouse model at least, HBV replication is inhibited by any stimulus that induces IFN $\gamma$ - or IFN $\alpha / \beta$ in the liver, including CD4 ${ }^{+}$T cells [46], NK and NKT cells [47], and other hepatotropic viral [48] parasitic infections $[49,50]$ and toll-like receptor activation [51]. This raises the possibility that HBV infection can be controlled by many arms of the immune response, and perhaps explains why HBV infection is almost always self-limited in immunologically normal adults.

To investigate whether these principles apply to the clearance of HBV infection, we extended these studies to HBV-infected chimpanzees [4,5]. Intrahepatic gene expression profiling in these animals revealed that the early phase of clearance of HBV (Figure 1c), and parenthetically also for HCV (Figure 1d) [25], was temporally associated with the appearance of CD3, CD8 and IFN $\gamma$ mRNA and other T cell-derived and interferon gamma (IFN $\gamma$ )-stimulated genes, some of which might contribute to the noncytopathic inhibition described above $[5,9,52]$. These transcriptional changes were reflected by the influx of virus-specific CD8+ T cells into the liver [5]. But, although HBV replicative intermediates $[5,53]$ decreased as much as 50-fold from peak levels during this time, there was little or no attendant liver disease, despite the fact that virtually $100 \%$ of the hepatocytes were infected $[4,5]$ suggesting that noncytopathic mechanisms were active during this early phase of viral clearance. Interestingly, the HBV transcriptional template (cccDNA) that is not expressed in HBV transgenic mice also decreased 8 fold during the same period of time, suggesting that cccDNA could, at least partially, be eliminated from hepatocytes by a non-cytolytic mechanism [53]. Furthermore, we also showed that monoclonal antibody mediated depletion of CD8+ T cells (but not CD4+ T cells) at the peak of infection delayed the onset of viral clearance and liver disease for several weeks until the antibody titers waned and virusspecific CD8+ T cells became detectable in the liver [5]. Thus, we conclude that the principle of CD8-dependent cytopathic and noncytopathic clearance of HBV (Figure 2), which was discovered in the HBV transgenic mouse model [37], is operative in the context of the full fledged viral infection $[4,5,53]$.

\section{Mechanisms of HBV Persistence}

Neonatal tolerance to $\mathrm{HBV}$ is probably responsible for viral persistence following motherinfant transmission [6]. Neonatal tolerance to HBV might be induced by the HBV precore protein $(\mathrm{HBeAg})$ that has the capacity to cross the placenta and induce neonatal tolerance in HBV transgenic mice [54]. On the other hand, the basis for the inadequate immune response that is characteristic of adult onset chronic HBV infections is not well understood, and may in fact be multifactorial and be influenced by the size of the viral inoculum as described below. Potential contributing factors to HBV persistence in adult HBV infection include mutational escape leading to inactivation of B-cell and T-cell epitopes (reviewed in [2,23]) and specific inhibition of the adaptive immune response by viral proteins. For example, 
HBeAg has been shown to suppress the antibody and $\mathrm{T}$ cell response to HBcAg in adult $\mathrm{T}$ cell receptor transgenic mice [55]. Thus, HBeAg may suppress immune elimination of infected cells by $\mathrm{HBcAg}$-specific $\mathrm{T}$ cells and, thereby, contribute to viral persistence in chronically infected adults consistent with the clinical observation that viral mutations that preclude the production of $\mathrm{HBeAg}$ are often associated with exacerbations of liver disease and, sometimes, even with viral clearance in chronically infected patients $[8,56]$. The hepatitis B surface antigen (HBsAg) might also suppress immune elimination of infected cells by functioning as a high dose tolerogen since extremely high serum HBsAg titers in the $\mathrm{mg}$ per $\mathrm{ml}$ range are often seen in chronically infected patients $[57,58]$ and chronically infected patients display absent or subnormal levels of HBsAg-specific CD8+ T cells [58]. In addition, HBV X protein, a transcriptional transactivator that is required for initiation of infection [59,60], can inhibit cellular proteasome activity when it is overexpressed [61] and thereby might interfere with antigen processing and presentation.

\section{The Size of the Viral Inoculum Contributes to the Outcome of HBV Infection}

Recent studies in HBV infected chimpanzees using a wide dose range of a single monoclonal HBV inoculum demonstrated that also the size of the viral inoculum contributes to the outcome of HBV infection [21]. As shown in Figure 3a-c, animals inoculated with $10^{10}, 10^{7}$ and $10^{4}$ genome equivalents (GE) of HBV cleared the virus within 8-30 weeks after its first detection, in a virus dose-related fashion similar to what we have previously observed in several other animals that had been inoculated with $10^{8}$ GE HBV [4,5]. In contrast, both of the animals that were inoculated with $10^{1} \mathrm{GE}$ became chronically infected (Figure $3 \mathrm{~d}$ and e), one of which (like many chronically infected humans) ultimately cleared the virus in the context of an acute disease flare 42 weeks after first detection, while the other remained heavily infected for at least 55 weeks at which point the study was terminated. This suggests that a virus dose window exists between $10^{4}$ and $10^{1} \mathrm{GE}$ within which the host-virus dynamics favor persistent infections, while higher doses favor viral clearance. Importantly, viral clearance (Figure $3 \mathrm{a}-\mathrm{c}$ ) was heralded by early $\mathrm{CD} 4^{+} \mathrm{T}$ cell priming either before or at the onset of detectable viral spread, and it coincided with a sharply synchronized influx of $\mathrm{HBV}$-specific $\mathrm{CD} 8^{+} \mathrm{T}$ cells into the liver and a corresponding increase in intrahepatic CD8 mRNA, serum ALT activity and histological evidence of acute viral hepatitis. Interestingly, the first detectable peripheral CD4 T cell response occurred during or before the phase of detectable viral expansion in the animals that cleared the infection in this study [21]. In contrast, the CD4 response was delayed until after the onset of viral expansion in the animals that developed persistent infection (Figure $3 \mathrm{~d}$ and e) at which point the virus had infected $100 \%$ of the hepatocytes [21] and there was an uncoordinated influx of $\mathrm{HBV}$-specific $\mathrm{CD} 8^{+} \mathrm{T}$ cells into the liver and a correspondingly asynchronous increase in intrahepatic CD8 mRNA and serum ALT activity [21].

\section{Early Priming of the CD4 T Cell Response is Required for Viral Clearance}

These fascinating results suggest that an early $\mathrm{CD} 4^{+} \mathrm{T}$ cell response to $\mathrm{HBV}$ infection is required to induce the $\mathrm{CD} 8^{+} \mathrm{T}$ cell response that clears the infection. Indeed, inoculation of an animal that was immuno-depleted of $\mathrm{CD}^{+}$cells with a virus dose $\left(10^{4} \mathrm{GE} \mathrm{HBV}\right)$ that should have been terminated in the context of a $\mathrm{T}$ cell response resulted in persistent $\mathrm{HBV}$ infection [21] (Figure 4). Importantly, CD4 T cell immunodepletion using the same antibody had no impact on the outcome of infection when it was delayed until 6 weeks after inoculation, i.e. at the peak of HBV infection, with the same inoculum in another chimpanzee [5]. Collectively, these results suggest that the timing of $\mathrm{CD}^{+} \mathrm{T}$ cell priming relative to the kinetics of viral spread is a key element in determining the magnitude and quality of the subsequent $\mathrm{CD} 8^{+} \mathrm{T}$ cell response to $\mathrm{HBV}$ and, therefore, the outcome of $\mathrm{HBV}$ infection. Since early $\mathrm{CD}^{+} \mathrm{T}$ cell priming in high dose $\mathrm{HBV}$ infections was observed in 
some animals prior to detectable viremia (Figure $3 \mathrm{~b}$ and c) and antigenemia [21], it was likely triggered by noninfectious subviral antigens that are in large molar excess ( 4 logs) relative to the number of infectious virions in the inoculum. Collectively, these results are consistent with the hypothesis that the early $\mathrm{CD} 4+\mathrm{T}$ cell priming is required to activate professioinal antigen presenting cells necessary for the induction of efficient antiviral CD8+ cytotoxic T lymphocyte (CTL) responses [62,63]. In contrast, in the absence of early CD4+ $\mathrm{T}$ cell responses, CD8+ T cell priming could occur in the liver, which has been shown to result in T cell inactivation, tolerance or apoptosis [64-66].

\section{Mechanisms of Hepatocarcinogenesis During HBV Infection}

Multifactorial mechanisms contribute to the development of hepatocellular carcinoma (HCC) in chronic HBV infection. Both viral and host factors including genetic alterations induced by viral DNA integration, expression of oncogenic viral proteins and chronic immune-mediated hepatitis (Figure 5) have been implicated as contributing factors [1,2,67].

\section{Integration of hepatitis B virus DNA}

It has been long recognized that most tumors in HBV associated HCC contain clonally integrated HBV DNA and microdeletions in the flanking cellular DNA which could deregulate cellular growth control mechanisms [68]. Indeed, in HCCs developed in woodchucks infected with woodchuck hepatitis B virus (WHV), WHV DNA insertions predominantly occur in the $\mathrm{N}-\mathrm{myc} 2$ oncogene which leads to N-myc2 activation [69-71]. Recent studies of HBV insertions in HBV-related HCCs revealed that also HBV integration can occur in genes that target telomerase and mixed lineage leukemia encoding genes suggesting potentially common pathways in HBV-related carcinogenesis [72-76]. HBV DNA integration has also been observed in patients with chronic hepatitis suggesting that integration is likely an early step in the process of hepatocarcinogenesis [77]. However, HBV integration is not likely occur in resting hepatocytes. Thus, if integration of the HBV genome contributes to hepatocarcinogenesis, it is likely to be secondary to procarcinogenic events that trigger hepatocyte turnover (e.g., immune-mediated hepatitis) as described below.

\section{Role of viral proteins}

In addition to integration, it is possible that certain HBV proteins may directly participate in HCC development. For example, the HBV X ( $\mathrm{HBx})$ gene product has been shown to transactivate cellular genes associated with cellular growth control [78-80]. The HBV X protein has also been shown to interact and interfere with numerous transcription factors [including $\mathrm{Ca}(2+)$ /cAMP-response element binding protein (CREB), activating transcription factor 3 (ATF)], nuclear factor interleukin- 6 (NFIL6), early growth response-1 (Egr1), Ets-1, octamer-binding protein (Oct1), and retinoid x receptor (RXR)], tumor suppressor genes (including p53), and proteins involved in DNA repair functions (including p53 and UVDDB1) (reviewed in $[67,81]$. Furthermore, HBx sequences with C-terminal deletions and point mutations have been detected in chronic hepatitis and HCC $[82,83]$, and since these mutations seem to arise before the development of HCC [84], these results suggest that deregulated $\mathrm{X}$ gene expression from integrated fragments of subviral DNA could play a role in hepatocarcinogenesis $[67,85]$. Similarly, a C-terminally truncated version of the HBV middle envelope protein (M-HBs) has been shown to be expressed from integrated subviral DNA in HCC and exert transcriptional activator activity [86,87]. Likewise, the HBV large envelope (L-HBs) has been shown to be a transcriptional transactivator [88]. Thus, these viral products, expressed from integrated viral DNA or replicating virus may contribute to hepatocarcinogenesis by their capacity to activate a variety of cellular promoters (including AP-1 and NF- $\mathrm{BB}$ ) [88-90]. 


\section{Immune mediated liver injury}

Almost all cases of HCC take place after many years of chronic immune-mediated hepatitis [6] characterized by continuous cycles of low-level liver cell destruction and regeneration that (over long periods of time) lead to fibrosis, cirrhosis, steatosis, and probably HCC. Indeed, transgenic mice that produce hepatotoxic quantities of L-HBs [91-94] display hepatocellular injury, regenerative hyperplasia, chronic inflammation, Kupffer cell hyperplasia, oxygen radical production, glutathione depletion, oxidative DNA damage, transcriptional deregulation and aneuploidy that inexorably progresses to HCC. [92,94-98] More importantly, transgenic mice that express nontoxic concentrations of the HBV envelope proteins in the hepatocyte and don't develop evidence of liver disease, develop HCC after many months of chronic hepatitis mediated by HBV-specific CTLs [99]. Importantly, the appearance of HCC in these settings occurs despite the absence of cofactors such as viral integration and $\mathrm{X}$ gene expression that have been discussed above. Since the immunological, virological and histological features of this chronic immune-mediated HCC model closely resemble the features of human chronic hepatitis, the results suggest that an ineffective immune response is a critical oncogenic factor during chronic HBV infection in man. The pathogenetic importance of immune-mediated hepatocellular injury in hepatocarcinogenesis in $\mathrm{HBV}$ is strengthened by the fact that hepatocellular carcinoma occurs in the context of necrosis, inflammation and regeneration (cirrhosis) in several human liver diseases other than hepatitis B, including chronic hepatitis C [100], alcoholism, [101] hemochromatosis, [102] glycogen storage disease, [103] a-1-antitrypsin deficiency, $[104,105]$ and primary biliary cirrhosis. [106] Irrespective of etiology or pathogenesis, therefore, it would appear that chronic liver cell injury is a premalignant condition that initiates a cascade of events characterized by increased rates of cellular DNA synthesis and production of endogenous mutagens coupled with compromised cellular detoxification and repair functions. If these processes are sustained for a sufficiently long period of time, they would be expected to cause the multiple genetic and chromosomal changes necessary to trigger the development of hepatocellular carcinoma (Figure 5).

\section{Summary and Conclusions}

In summary, HBV acts like a stealth virus early in infection, remaining undetected and spreading until the onset of the adaptive immune response several weeks later. The relative invisibility of HBV to the innate sensing machinery of the cells probably reflects its replication strategy with the replicating viral genome being sheltered within viral capsid particles in the cytoplasm. On the other hand, HBV can be controlled when properly activated HBV-specific CD8+ T cells enter the liver, recognize antigen, kill infected cells, and secrete IFN $\gamma$ which triggers a broad-based cascade that amplifies the inflammatory process and has noncytopathic antiviral activity against HBV. However, establishment of an effective adaptive antiviral immune response is dependent on $\mathrm{CD}^{+} \mathrm{T}$ cells and their priming early in infection most likely triggered by the subviral antigens present in the inoculum rather than by the infectious virions. Failure to trigger early CD4+ T cell responses, as occurs in low dose infections, induces functionally impaired CD8+ T cell responses resulting in the establishment of persistent infection. The inefficient immune response to HBV during chronic HBV infection results in low-level liver cell destruction and regeneration over long periods of time that lead to fibrosis, cirrhosis, steatosis, and eventually HCC.

\section{Acknowledgments}

We thank all of our colleagues who contributed importantly to the work cited in this review, especially Robert Purcell (NIAID, National Institutes of Health, Bethesda, MD), David Milich (Vaccine Research Institute of San Diego, San Diego, USA), Antonio Bertolleti (Singapore Institute for Clinical Sciences, Singapore, Singapore), 
Carlo Ferrari (Laboratory of Viral Immunopathology, Parma, Italy), Barbara Reherman (NIDDK, National Institutes of Health, Bethesda, USA), Michael Robek (Yale University, New Haven, USA), Robert Thimme (University Hospital Freiburg, Freiburg, Germany), and Luca Guidotti (The Scripps Research Institute, La Jolla, USA). These studies were supported by grants AI20001, CA40489 and CA54560 from the National Institute of Health. This is manuscript number 20426 of The Scripps Research Institute.

\section{References}

[1]. Chisari FV. Rous-Whipple Award Lecture. Viruses, immunity, and cancer: lessons from hepatitis B. Am J Pathol 2000;156:1117-32. [PubMed: 10751335]

[2]. Guidotti LG, Chisari FV. Immunobiology and pathogenesis of viral hepatitis. Annu Rev Pathol 2006;1:23-61. [PubMed: 18039107]

[3]. Guidotti LG, Matzke B, Schaller H, Chisari FV. High-level hepatitis B virus replication in transgenic mice. J Virol 1995;69:6158-69. [PubMed: 7666518]

[4]. Guidotti LG, Rochford R, Chung J, Shapiro M, Purcell R, Chisari FV. Viral clearance without destruction of infected cells during acute HBV infection. Science 1999;284:825-9. [PubMed: 10221919]

[5]. Thimme R, Wieland S, Steiger C, Ghrayeb J, Reimann KA, Purcell RH, et al. CD8(+) T cells mediate viral clearance and disease pathogenesis during acute hepatitis B virus infection. J Virol 2003;77:68-76. [PubMed: 12477811]

[6]. Chisari FV, Ferrari C. Hepatitis B virus immunopathogenesis. Annu Rev Immunol 1995;13:29-60. [PubMed: 7612225]

[7]. Ferrari C, Missale G, Boni C, Urbani S. Immunopathogenesis of hepatitis B. J Hepatol 2003;39(Suppl 1):S36-42. [PubMed: 14708676]

[8]. Ganem D, Prince AM. Hepatitis B virus infection--natural history and clinical consequences. N Engl J Med 2004;350:1118-29. [PubMed: 15014185]

[9]. Wieland S, Thimme R, Purcell RH, Chisari FV. Genomic analysis of the host response to hepatitis B virus infection. Proc Natl Acad Sci U S A 2004;101:6669-74. [PubMed: 15100412]

[10]. Missale G, Redeker A, Person J, Fowler P, Guilhot S, Schlicht HJ, et al. HLA-A31- and HLAAw68-restricted cytotoxic T cell responses to a single hepatitis B virus nucleocapsid epitope during acute viral hepatitis. J Exp Med 1993;177:751-62. [PubMed: 7679709]

[11]. Penna A, Chisari FV, Bertoletti A, Missale G, Fowler P, Giuberti T, et al. Cytotoxic T lymphocytes recognize an HLA-A2-restricted epitope within the hepatitis B virus nucleocapsid antigen. J Exp Med 1991;174:1565-70. [PubMed: 1720813]

[12]. Nayersina R, Fowler P, Guilhot S, Missale G, Cerny A, Schlicht HJ, et al. HLA A2 restricted cytotoxic T lymphocyte responses to multiple hepatitis B surface antigen epitopes during hepatitis B virus infection. J Immunol 1993;150:4659-71. [PubMed: 7683326]

[13]. Rehermann B, Fowler P, Sidney J, Person J, Redeker A, Brown M, et al. The cytotoxic T lymphocyte response to multiple hepatitis B virus polymerase epitopes during and after acute viral hepatitis. J Exp Med 1995;181:1047-58. [PubMed: 7532675]

[14]. Rehermann B. Intrahepatic T cells in hepatitis B: viral control versus liver cell injury. J Exp Med 2000;191:1263-8. [PubMed: 10770794]

[15]. Bertoletti A, Ferrari C, Fiaccadori F, Penna A, Margolskee R, Schlicht HJ, et al. HLA class Irestricted human cytotoxic $\mathrm{T}$ cells recognize endogenously synthesized hepatitis B virus nucleocapsid antigen. Proc Natl Acad Sci U S A 1991;88:10445-9. [PubMed: 1660137]

[16]. Bertoni R, Sette A, Sidney J, Guidotti LG, Shapiro M, Purcell R, et al. Human class I supertypes and CTL repertoires extend to chimpanzees. J Immunol 1998;161:4447-55. [PubMed: 9780224]

[17]. Maini MK, Boni C, Ogg GS, King AS, Reignat S, Lee CK, et al. Direct ex vivo analysis of hepatitis B virus-specific CD8(+) T cells associated with the control of infection. Gastroenterology 1999;117:1386-96. [PubMed: 10579980]

[18]. Rehermann B, Ferrari C, Pasquinelli C, Chisari FV. The hepatitis B virus persists for decades after patients' recovery from acute viral hepatitis despite active maintenance of a cytotoxic Tlymphocyte response. Nat Med 1996;2:1104-8. [PubMed: 8837608] 
[19]. Thimme R, Chang KM, Pemberton J, Sette A, Chisari FV. Degenerate immunogenicity of an HLA-A2-restricted hepatitis B virus nucleocapsid cytotoxic T-lymphocyte epitope that is also presented by HLA-B51. J Virol 2001;75:3984-7. [PubMed: 11264388]

[20]. Boni C, Penna A, Ogg GS, Bertoletti A, Pilli M, Cavallo C, et al. Lamivudine treatment can overcome cytotoxic T-cell hyporesponsiveness in chronic hepatitis B: new perspectives for immune therapy. Hepatology 2001;33:963-71. [PubMed: 11283861]

[21]. Asabe S, Wieland SF, Chattopadhyay PK, Roederer M, Engle RE, Purcell RH, et al. The size of the viral inoculum contributes to the outcome of hepatitis B virus infection. J Virol 2009;83:9652-62. [PubMed: 19625407]

[22]. Samuel CE. Antiviral actions of interferon. Interferon-regulated cellular proteins and their surprisingly selective antiviral activities. Virology 1991;183:1-11. [PubMed: 1711253]

[23]. Wieland SF, Chisari FV. Stealth and cunning: hepatitis B and hepatitis C viruses. J Virol 2005;79:9369-80. [PubMed: 16014900]

[24]. Bigger CB, Brasky KM, Lanford RE. DNA microarray analysis of chimpanzee liver during acute resolving hepatitis C virus infection. J Virol 2001;75:7059-66. [PubMed: 11435586]

[25]. Su AI, Pezacki JP, Wodicka L, Brideau AD, Supekova L, Thimme R, et al. Genomic analysis of the host response to hepatitis C virus infection. Proc Natl Acad Sci U S A 2002;99:15669-74. [PubMed: 12441396]

[26]. Summers J. The replication cycle of hepatitis B viruses. Cancer 1988;61:1957-62. [PubMed: 2834035]

[27]. Seeger C, Mason WS. Hepatitis B virus biology. Microbiol Mol Biol Rev 2000;64:51-68. [PubMed: 10704474]

[28]. Guidotti LG, Borrow P, Hobbs MV, Matzke B, Gresser I, Oldstone MB, et al. Viral cross talk: intracellular inactivation of the hepatitis B virus during an unrelated viral infection of the liver. Proc Natl Acad Sci U S A 1996;93:4589-94. [PubMed: 8643448]

[29]. Wieland SF, Guidotti LG, Chisari FV. Intrahepatic induction of alpha/beta interferon eliminates viral RNA-containing capsids in hepatitis B virus transgenic mice. J Virol 2000;74:4165-73. [PubMed: 10756029]

[30]. Tsui LV, Guidotti LG, Ishikawa T, Chisari FV. Posttranscriptional clearance of hepatitis B virus RNA by cytotoxic T lymphocyte-activated hepatocytes. Proc Natl Acad Sci U S A 1995;92:12398-402. [PubMed: 8618909]

[31]. Moss B, Smith GL, Gerin JL, Purcell RH. Live recombinant vaccinia virus protects chimpanzees against hepatitis B. Nature 1984;311:67-9. [PubMed: 6472464]

[32]. Ferrari C, Penna A, Bertoletti A, Valli A, Antoni AD, Giuberti T, et al. Cellular immune response to hepatitis B virus-encoded antigens in acute and chronic hepatitis B virus infection. Journal of Immunology 1990;145:3442-9.

[33]. Jung MC, Spengler U, Schraut W, Hoffmann R, Zachoval R, Eisenburg J, et al. Hepatitis B virus antigen-specific T-cell activation in patients with acute and chronic hepatitis B. J Hepatol 1991;13:310-7. [PubMed: 1808224]

[34]. Maini MK, Boni C, Lee CK, Larrubia JR, Reignat S, Ogg GS, et al. The role of virus-specific $\mathrm{CD} 8(+)$ cells in liver damage and viral control during persistent hepatitis B virus infection. J Exp Med 2000;191:1269-80. [PubMed: 10770795]

[35]. Ando K, Guidotti LG, Wirth S, Ishikawa T, Missale G, Moriyama T, et al. Class I-restricted cytotoxic T lymphocytes are directly cytopathic for their target cells in vivo. J Immunol 1994;152:3245-53. [PubMed: 8144915]

[36]. Moriyama T, Guilhot S, Klopchin K, Moss B, Pinkert CA, Palmiter RD, et al. Immunobiology and pathogenesis of hepatocellular injury in hepatitis B virus transgenic mice. Science 1990;248:361-4. [PubMed: 1691527]

[37]. Guidotti LG, Ishikawa T, Hobbs MV, Matzke B, Schreiber R, Chisari FV. Intracellular inactivation of the hepatitis B virus by cytotoxic T lymphocytes. Immunity 1996;4:25-36. [PubMed: 8574849]

[38]. Guidotti LG, Ando K, Hobbs MV, Ishikawa T, Runkel L, Schreiber RD, et al. Cytotoxic T lymphocytes inhibit hepatitis B virus gene expression by a noncytolytic mechanism in transgenic mice. Proc Natl Acad Sci U S A 1994;91:3764-8. [PubMed: 8170985] 
[39]. Wieland SF, Eustaquio A, Whitten-Bauer C, Boyd B, Chisari FV. Interferon prevents formation of replication-competent hepatitis B virus RNA-containing nucleocapsids. Proc Natl Acad Sci U S A 2005;102:9913-7. [PubMed: 15994231]

[40]. Robek MD, Wieland SF, Chisari FV. Inhibition of hepatitis B virus replication by interferon requires proteasome activity. J Virol 2002;76:3570-4. [PubMed: 11884582]

[41]. Robek MD, Boyd BS, Wieland SF, Chisari FV. Signal transduction pathways that inhibit hepatitis B virus replication. Proc Natl Acad Sci U S A 2004;101:1743-7. [PubMed: 14757813]

[42]. Heise T, Guidotti LG, Chisari FV. Characterization of nuclear RNases that cleave hepatitis B virus RNA near the La protein binding site. J Virol 2001;75:6874-83. [PubMed: 11435567]

[43]. Heise T, Guidotti LG, Chisari FV. La autoantigen specifically recognizes a predicted stem-loop in hepatitis B virus RNA. J Virol 1999;73:5767-76. [PubMed: 10364328]

[44]. Heise T, Guidotti LG, Cavanaugh VJ, Chisari FV. Hepatitis B virus RNA-binding proteins associated with cytokine-induced clearance of viral RNA from the liver of transgenic mice. $\mathbf{J}$ Virol 1999;73:474-81. [PubMed: 9847353]

[45]. McClary H, Koch R, Chisari FV, Guidotti LG. Relative sensitivity of hepatitis B virus and other hepatotropic viruses to the antiviral effects of cytokines. J Virol 2000;74:2255-64. [PubMed: 10666256]

[46]. Franco A, Guidotti LG, Hobbs MV, Pasquetto V, Chisari FV. Pathogenetic effector function of CD4-positive T helper 1 cells in hepatitis B virus transgenic mice. J Immunol 1997;159:2001-8. [PubMed: 9257867]

[47]. Kakimi K, Guidotti LG, Koezuka Y, Chisari FV. Natural killer T cell activation inhibits hepatitis B virus replication in vivo. Journal of Experimental Medicine 2000;192:921-30. [PubMed: 11015434]

[48]. Cavanaugh VJ, Guidotti LG, Chisari FV. Inhibition of hepatitis B virus replication during adenovirus and cytomegalovirus infections in transgenic mice. J Virol 1998;72:2630-7. [PubMed: 9525579]

[49]. Pasquetto V, Guidotti LG, Kakimi K, Tsuji M, Chisari FV. Host-virus interactions during malaria infection in hepatitis B virus transgenic mice. J Exp Med 2000;192:529-36. [PubMed: 10952722]

[50]. McClary H, Koch R, Chisari FV, Guidotti LG. Inhibition of hepatitis B virus replication during schistosoma mansoni infection in transgenic mice. J Exp Med 2000;192:289-94. [PubMed: 10899915]

[51]. Isogawa M, Robek MD, Furuichi Y, Chisari FV. Toll-like receptor signaling inhibits hepatitis B virus replication in vivo. J Virol 2005;79:7269-72. [PubMed: 15890966]

[52]. Wieland SF, Vega RG, Muller R, Evans CF, Hilbush B, Guidotti LG, et al. Searching for interferon-induced genes that inhibit hepatitis B virus replication in transgenic mouse hepatocytes. J Virol 2003;77:1227-36. [PubMed: 12502840]

[53]. Wieland SF, Spangenberg HC, Thimme R, Purcell RH, Chisari FV. Expansion and contraction of the hepatitis B virus transcriptional template in infected chimpanzees. Proc Natl Acad Sci U S A 2004;101:2129-34. [PubMed: 14764900]

[54]. Milich DR, Jones JE, Hughes JL, Price J, Raney AK, McLachlan A. Is a function of the secreted hepatitis B e antigen to induce immunologic tolerance in utero? Proc Natl Acad Sci U S A 1990;87:6599-603. [PubMed: 2395863]

[55]. Chen MT, Billaud JN, Sallberg M, Guidotti LG, Chisari FV, Jones J, et al. A function of the hepatitis B virus precore protein is to regulate the immune response to the core antigen. Proc Natl Acad Sci U S A 2004;101:14913-8. [PubMed: 15469922]

[56]. Brunetto MR, Giarin MM, Oliveri F, Chiaberge E, Baldi M, Alfarano A, et al. Wild-type and e antigen-minus hepatitis B viruses and course of chronic hepatitis. Proc Natl Acad Sci U S A 1991;88:4186-90. [PubMed: 2034663]

[57]. Webster GJ, Reignat S, Brown D, Ogg GS, Jones L, Seneviratne SL, et al. Longitudinal analysis of CD8+ T cells specific for structural and nonstructural hepatitis B virus proteins in patients with chronic hepatitis B: implications for immunotherapy. J Virol 2004;78:5707-19. [PubMed: 15140968] 
[58]. Reignat S, Webster GJ, Brown D, Ogg GS, King A, Seneviratne SL, et al. Escaping high viral load exhaustion: CD8 cells with altered tetramer binding in chronic hepatitis B virus infection. $\mathrm{J}$ Exp Med 2002;195:1089-101. [PubMed: 11994415]

[59]. Zoulim F, Saputelli J, Seeger C. Woodchuck hepatitis virus X protein is required for viral infection in vivo. J Virol 1994;68:2026-30. [PubMed: 8107266]

[60]. Zhang Z, Torii N, Hu Z, Jacob J, Liang TJ. X-deficient woodchuck hepatitis virus mutants behave like attenuated viruses and induce protective immunity in vivo. J Clin Invest 2001;108:1523-31. [PubMed: 11714744]

[61]. Hu Z, Zhang Z, Doo E, Coux O, Goldberg AL, Liang TJ. Hepatitis B virus X protein is both a substrate and a potential inhibitor of the proteasome complex. J Virol 1999;73:7231-40. [PubMed: 10438810]

[62]. Sallusto F, Lanzavecchia A. Mobilizing dendritic cells for tolerance, priming, and chronic inflammation. J Exp Med 1999;189:611-4. comment. [PubMed: 9989975]

[63]. Steinman RM, Inaba K, Turley S, Pierre P, Mellman I. Antigen capture, processing, and presentation by dendritic cells: recent cell biological studies. Hum Immunol 1999;60:562-7. [PubMed: 10426272]

[64]. Bertolino P, McCaughan GW, Bowen DG. Role of primary intrahepatic T-cell activation in the 'liver tolerance effect'. Immunol Cell Biol 2002;80:84-92. [PubMed: 11869365]

[65]. Crispe IN. Hepatic T cells and liver tolerance. Nat Rev Immunol 2003;3:51-62. [PubMed: 12511875]

[66]. Isogawa M, Furuichi Y, Chisari FV. Oscillating CD8(+) T cell effector functions after antigen recognition in the liver. Immunity 2005;23:53-63. [PubMed: 16039579]

[67]. Kremsdorf D, Soussan P, Paterlini-Brechot P, Brechot C. Hepatitis B virus-related hepatocellular carcinoma: paradigms for viral-related human carcinogenesis. Oncogene 2006;25:3823-33. [PubMed: 16799624]

[68]. Matsubara K, Tokino T. Integration of hepatitis B virus DNA and its implications for hepatocarcinogenesis. Mol Biol Med 1990;7:243-60. [PubMed: 2170810]

[69]. Buendia MA. Mammalian hepatitis B viruses and primary liver cancer. Semin Cancer Biol 1992;3:309-20. [PubMed: 1335794]

[70]. Bruni R, D'Ugo E, Giuseppetti R, Argentini C, Rapicetta M. Activation of the N-myc2 oncogene by woodchuck hepatitis virus integration in the linked downstream b3n locus in woodchuck hepatocellular carcinoma. Virology 1999;257:483-90. [PubMed: 10329558]

[71]. Bruni R, D'Ugo E, Villano U, Fourel G, Buendia MA, Rapicetta M. The win locus involved in activation of the distal N-myc2 gene upon WHV integration in woodchuck liver tumors harbors S/MAR elements. Virology 2004;329:1-10. [PubMed: 15476869]

[72]. Paterlini-Brechot P, Saigo K, Murakami Y, Chami M, Gozuacik D, Mugnier C, et al. Hepatitis B virus-related insertional mutagenesis occurs frequently in human liver cancers and recurrently targets human telomerase gene. Oncogene 2003;22:3911-6. [PubMed: 12813464]

[73]. Murakami Y, Saigo K, Takashima H, Minami M, Okanoue T, Brechot C, et al. Large scaled analysis of hepatitis B virus (HBV) DNA integration in HBV related hepatocellular carcinomas. Gut 2005;54:1162-8. [PubMed: 16009689]

[74]. Tamori A, Yamanishi Y, Kawashima S, Kanehisa M, Enomoto M, Tanaka H, et al. Alteration of gene expression in human hepatocellular carcinoma with integrated hepatitis B virus DNA. Clin Cancer Res 2005;11:5821-6. [PubMed: 16115921]

[75]. Ferber MJ, Montoya DP, Yu C, Aderca I, McGee A, Thorland EC, et al. Integrations of the hepatitis B virus (HBV) and human papillomavirus (HPV) into the human telomerase reverse transcriptase (hTERT) gene in liver and cervical cancers. Oncogene 2003;22:3813-20. [PubMed: 12802289]

[76]. Horikawa I, Barrett JC. cis-Activation of the human telomerase gene (hTERT) by the hepatitis B virus genome. J Natl Cancer Inst 2001;93:1171-3. [PubMed: 11481390]

[77]. Minami M, Daimon Y, Mori K, Takashima H, Nakajima T, Itoh Y, et al. Hepatitis B virusrelated insertional mutagenesis in chronic hepatitis $\mathrm{B}$ patients as an early drastic genetic change leading to hepatocarcinogenesis. Oncogene 2005;24:4340-8. [PubMed: 15806150] 
[78]. Kekule AS, Lauer U, Weiss L, Luber B, Hofschneider PH. Hepatitis B virus transactivator HBx uses a tumour promoter signalling pathway. Nature 1993;361:742-5. [PubMed: 8441471]

[79]. Maguire HF, Hoeffler JP, Siddiqui A. HBV X protein alters the DNA binding specificity of CREB and ATF-2 by protein-protein interactions. Science 1991;252:842-4. [PubMed: 1827531]

[80]. Natoli G, Avantaggiati ML, Chirillo P, Costanzo A, Artini M, Balsano C, et al. Induction of the DNA-binding activity of c-jun/c-fos heterodimers by the hepatitis B virus transactivator $\mathrm{pX}$. Mol Cell Biol 1994;14:989-98. [PubMed: 7507209]

[81]. Brechot C. Pathogenesis of hepatitis B virus-related hepatocellular carcinoma: old and new paradigms. Gastroenterology 2004;127:S56-61. [PubMed: 15508104]

[82]. Iavarone M, Trabut JB, Delpuech O, Carnot F, Colombo M, Kremsdorf D, et al. Characterisation of hepatitis B virus X protein mutants in tumour and non-tumour liver cells using laser capture microdissection. J Hepatol 2003;39:253-61. [PubMed: 12873823]

[83]. Leon B, Taylor L, Vargas M, Luftig RB, Albertazzi F, Herrero L, et al. HBx M130K and V131I (T-A) mutations in HBV genotype $\mathrm{F}$ during a follow-up study in chronic carriers. Virol $\mathrm{J}$ 2005;2:60. [PubMed: 16080797]

[84]. Kuang SY, Jackson PE, Wang JB, Lu PX, Munoz A, Qian GS, et al. Specific mutations of hepatitis B virus in plasma predict liver cancer development. Proc Natl Acad Sci U S A 2004;101:3575-80. [PubMed: 14990795]

[85]. Koike K, Moriya K, Iino S, Yotsuyanagi H, Endo Y, Miyamura T, et al. High-level expression of hepatitis B virus HBx gene and hepatocarcinogenesis in transgenic mice. Hepatology 1994;19:810-9. [PubMed: 8138251]

[86]. Caselmann WH, Meyer M, Kekule AS, Lauer U, Hofschneider PH, Koshy R. A trans-activator function is generated by integration of hepatitis B virus preS/S sequences in human hepatocellular carcinoma DNA. Proc Natl Acad Sci U S A 1990;87:2970-4. [PubMed: 2158099]

[87]. Kekule AS, Lauer U, Meyer M, Caselmann WH, Hofschneider PH, Koshy R. The preS2/S region of integrated hepatitis B virus DNA encodes a transcriptional transactivator. Nature 1990;343:457-61. [PubMed: 2153938]

[88]. Hildt E, Saher G, Bruss V, Hofschneider PH. The hepatitis B virus large surface protein (LHBs) is a transcriptional activator. Virology 1996;225:235-9. [PubMed: 8918553]

[89]. Caselmann WH, Renner M, Schluter V, Hofschneider PH, Koshy R, Meyer M. The hepatitis B virus MHBst167 protein is a pleiotropic transactivator mediating its effect via ubiquitous cellular transcription factors. J Gen Virol 1997;78(Pt 6):1487-95. [PubMed: 9191947]

[90]. Natoli G, Avantaggiati ML, Balsano C, De Marzio E, Collepardo D, Elfassi E, et al. Characterization of the hepatitis B virus preS/S region encoded transcriptional transactivator. Virology 1992;187:663-70. [PubMed: 1546461]

[91]. Chisari FV, Pinkert CA, Milich DR, Filippi P, McLachlan A, Palmiter RD, et al. A transgenic mouse model of the chronic hepatitis B surface antigen carrier state. Science 1985;230:1157-60. [PubMed: 3865369]

[92]. Chisari FV, Filippi P, Buras J, McLachlan A, Popper H, Pinkert CA, et al. Structural and pathological effects of synthesis of hepatitis B virus large envelope polypeptide in transgenic mice. Proc Natl Acad Sci U S A 1987;84:6909-13. [PubMed: 3477814]

[93]. Chisari FV, Filippi P, McLachlan A, Milich DR, Riggs M, Lee S, et al. Expression of hepatitis B virus large envelope polypeptide inhibits hepatitis B surface antigen secretion in transgenic mice. J Virol 1986;60:880-7. [PubMed: 3783819]

[94]. Chisari FV, Klopchin K, Moriyama T, Pasquinelli C, Dunsford HA, Sell S, et al. Molecular pathogenesis of hepatocellular carcinoma in hepatitis B virus transgenic mice. Cell 1989;59:1145-56. [PubMed: 2598264]

[95]. Dunsford HA, Sell S, Chisari FV. Hepatocarcinogenesis due to chronic liver cell injury in hepatitis B virus transgenic mice. Cancer Research 1990;50:3400-7. [PubMed: 1692259]

[96]. Hagen TM, Huang S, Curnutte J, Fowler P, Martinez V, Wehr CM, et al. Extensive oxidative DNA damage in hepatocytes of transgenic mice with chronic active hepatitis destined to develop hepatocellular carcinoma. Proc Natl Acad Sci U S A 1994;91:12808-12. [PubMed: 7809125] 
[97]. Huang SN, Chisari FV. Strong, sustained hepatocellular proliferation precedes hepatocarcinogenesis in hepatitis B surface antigen transgenic mice. Hepatology 1995;21:620-6. [PubMed: 7875658]

[98]. Pasquinelli C, Bhavani K, Chisari FV. Multiple oncogenes and tumor suppressor genes are structurally and functionally intact during hepatocarcinogenesis in hepatitis B virus transgenic mice. Cancer Research 1992;52:2823-9. [PubMed: 1316229]

[99]. Nakamoto Y, Guidotti LG, Kuhlen CV, Fowler P, Chisari FV. Immune pathogenesis of hepatocellular carcinoma. J Exp Med 1998;188:341-50. [PubMed: 9670046]

[100]. Alter, HJ. Viral Hepatitis and Liver Disease. Alan R. Liss; New York: 1988. Transfusionassociated non-A, non-B hepatitis: the first decade; p. 534-542.

[101]. Lieber CS, Garro A, Leo MA, Mak KM, Worner T. Alcohol and cancer. Hepatology 1986;6:1005-19. [PubMed: 3019860]

[102]. Niederau C, Fischer R, Sonnenberg A, Stremmel W, Trampisch HJ, Strohmeyer G. Survival and causes of death in cirrhotic and in noncirrhotic patients with primary hemochromatosis. N Engl J Med 1985;313:1256-62. [PubMed: 4058506]

[103]. Limmer J, Fleig WE, Leupold D, Bittner R, Ditschuneit H, Beger HG. Hepatocellular carcinoma in type I glycogen storage disease. Hepatology 1988;8:531-7. [PubMed: 2453430]

[104]. Carlson J, Eriksson S. Chronic 'cryptogenic' liver disease and malignant hepatoma in intermediate alpha 1-antitrypsin deficiency identified by a Pi Z-specific monoclonal antibody. Scand J Gastroenterol 1985;20:835-42. [PubMed: 2996119]

[105]. Eriksson S, Carlson J, Velez R. Risk of cirrhosis and primary liver cancer in alpha 1-antitrypsin deficiency. N Engl J Med 1986;314:736-9. [PubMed: 3485248]

[106]. Melia WM, Johnson PJ, Neuberger J, Zaman S, Portmann BC, Williams R. Hepatocellular carcinoma in primary biliary cirrhosis: detection by alpha-fetoprotein estimation. Gastroenterology 1984;87:660-3. [PubMed: 6204905]

[107]. Su AI, Guidotti LG, Pezacki JP, Chisari FV, Schultz PG. Gene expression during the priming phase of liver regeneration after partial hepatectomy in mice. Proc Natl Acad Sci U S A 2002;99:11181-6. [PubMed: 12177410] 

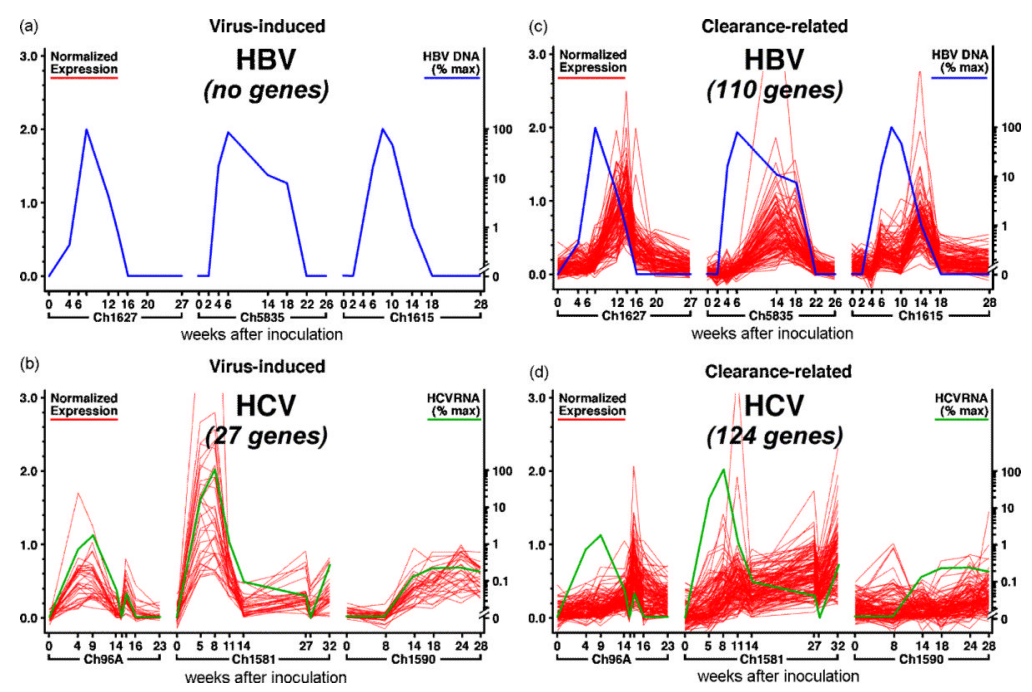

Figure 1.

Liver gene expression profile during HBV and HCV infection [9]. (A) Genes correlated with viremia in all acutely HBV infected chimpanzees. No genes correlated positively or negatively with the level of intrahepatic HBV DNA during the time course of acute HBV infection in all three animals. (B) Intrahepatic gene expression correlated with viremia in three HCV infected chimpanzees [107]. (C) Liver gene expression profile associated with viral clearance in all three acutely HBV-infected chimpanzees and (D) that associated with clearance in HCV infected chimpanzees [107]. Gene identities in HBV and HCV infected animals are described in Wieland et al [9] and Su et al [107], respectively. Blue and green lines show the intrahepatic HBV DNA or serum HCV RNA as a percentage (\% max) of the corresponding peak levels, respectively. For optimal visualization, gene expression levels (red lines) are shown after normalization to the 10th and 90th percentiles for each gene. Values on the $\mathrm{x}$ axis represent weeks after inoculation with HBV. Adapted from Wieland et al. (2004) PNAS vol. 101 pp. 6669-74 and Su et al. (2002) PNAS vol. 99 pp. 11181-6. 


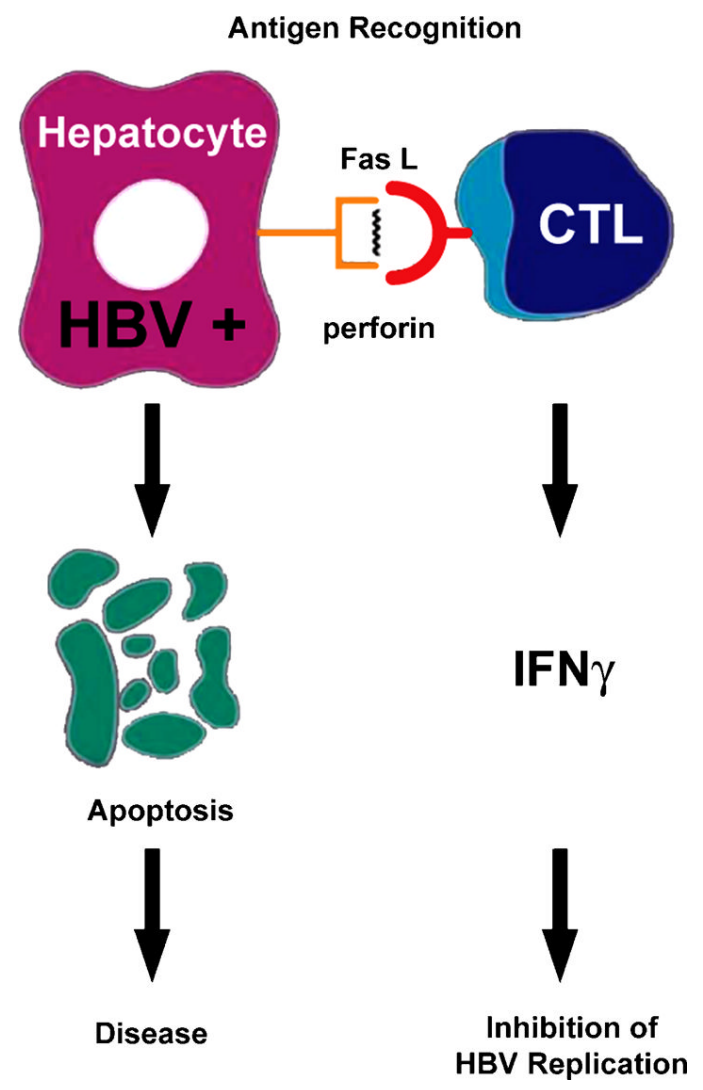

Figure 2.

Noncytopathic clearance of HBV from the hepatocyte by T cell- derived cytokines. On antigen recognition, CD8-positive CTL deliver an apoptotic signal to their target cells, killing them. They also secrete IFN $\gamma$ and TNF- $\alpha$, cytokines that abolish viral replication and HBV gene expression in vivo, potentially curing them. Reprinted/amended from Am J Pathol 2000, 156:1117-1132 with permission from the American Society for Investigative Pathology. 

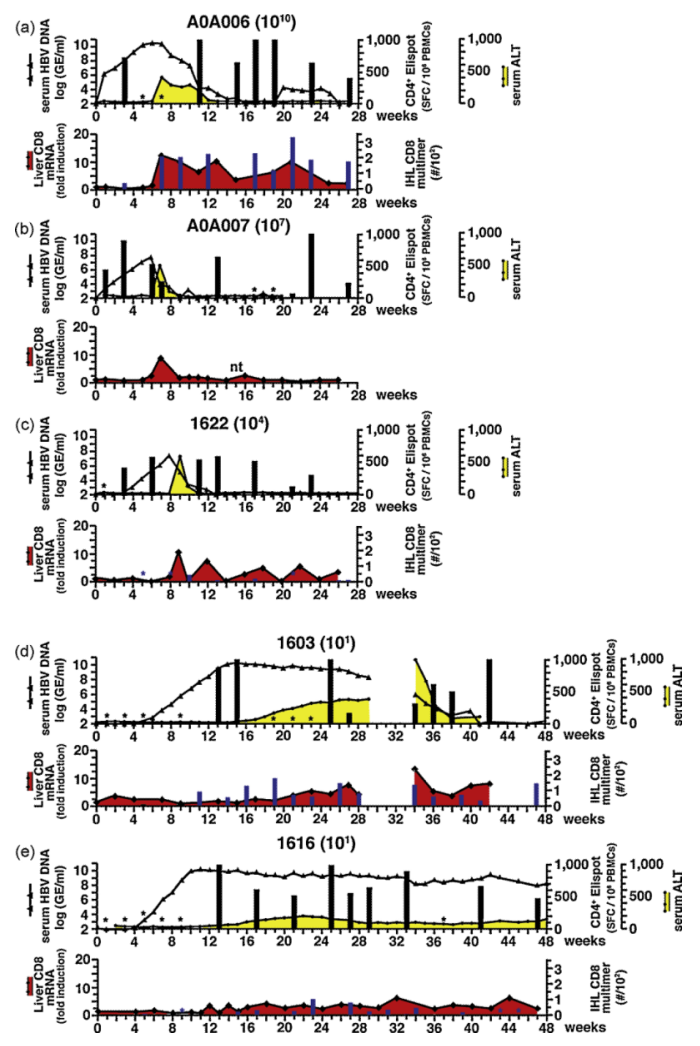

Figure 3.

Peripheral $\mathrm{CD}^{+}{ }^{+} \mathrm{T}$ cell responses against $\mathrm{HBV}$ core protein and intrahepatic $\mathrm{CD} 8^{+} \mathrm{T}$ cell responses in chimpanzees infected with a dose range of HBV as described in Asabe et al. [21]. The upper panel in each figure represents the serum HBV DNA as a black line and sALT as a yellow shaded area and the results of peripheral $\mathrm{CD} 4^{+} \mathrm{T}$ cell ELISPOT assays are overlaid as black bars. Cryopreserved PBMCs were thawed and stimulated in vitro with $\mathrm{HBV}$ core protein and the numbers of IFN $\gamma$ producing cells were determined by ELISPOT assay as described [21]. The data are shown as number of spots at each time point minus the number of spots before inoculation per million PBMCs. The lower panel shows the total number of intrahepatic HBV-specific $\mathrm{CD} 8^{+} \mathrm{T}$ cells per $10^{2}$ total $\mathrm{CD} 8^{+} \mathrm{T}$ cells as filled blue bars (right axis) and fold induction of intrahepatic CD8 mRNA compared to two preinoculation time points as a shaded red area (left axis). Intrahepatic lymphocytes were expanded antigen-nonspecifically in vitro and tested with all the corresponding Patr/peptide multimer complexes as described [21]. nt: not tested. *: tested and negative. Reproduced/ amended with permission from American Society for Microbiology from Journal of Virology, 2009, vol 83, pp. 9652-62, DOI: 10.1128/JVI.00867-09. 


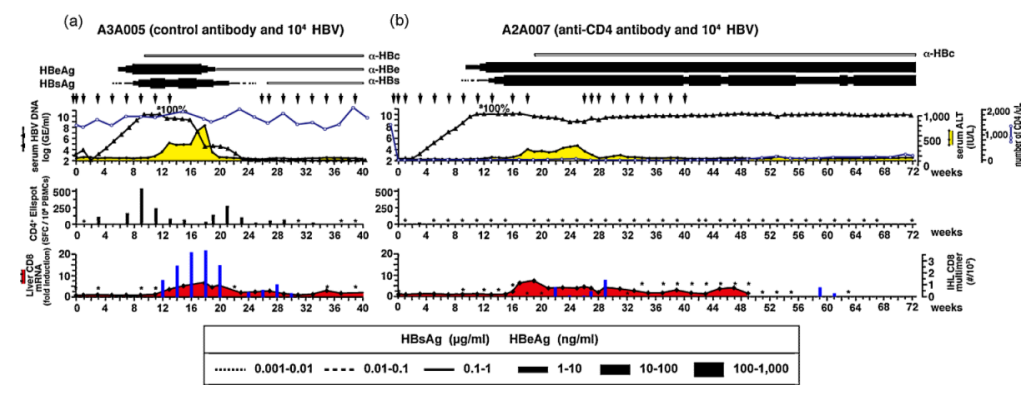

Figure 4.

Course of $\mathrm{HBV}$ infections, peripheral $\mathrm{CD} 4^{+} \mathrm{T}$ cell responses against $\mathrm{HBV}$ core protein, and intrahepatic $\mathrm{CD}^{+} \mathrm{T}$ cell responses in chimpanzees with or without $\mathrm{CD} 4$ immunodepletion as described in Asabe et al [21]. Serum HBV DNA levels are shown as a black line and sALT as a yellow shaded area. Horizontal bars represent serum HBe and HBs antigen levels and the open horizontal bars represent the presence of anti-HBc, anti-HBe, and anti-HBs antibodies. The amount of each protein is reflected by the thickness of each bar as indicated in the legend. The numbers of $\mathrm{CD} 4^{+} \mathrm{T}$ cells per $\mu \mathrm{L}$ of whole blood were shown as closed squares (top panel, right axis). Arrows on the top panels represent injections of control antibody (a) or anti-CD4 antibody (b). Peripheral CD4 ${ }^{+} \mathrm{T}$ cell IFN $\gamma$ ELISPOT assays against $\mathrm{HBV}$ core protein (second panel) and detection of intrahepatic $\mathrm{HBV}$-specific CD8 ${ }^{+}$ T cells (bottom panel, left axis) were as described in Figure 3 except that freshly prepared cells were used instead of using cryopreserved cells. Fold induction of intrahepatic CD8 mRNA compared to two preinoculation time points is shown as a shaded red area (bottom panel, right axis). *: tested and negative. Reproduced/amended with permission from American Society for Microbiology from Journal of Virology, 2009, vol 83, pp. 9652-62, DOI: 10.1128/JVI.00867-09. 


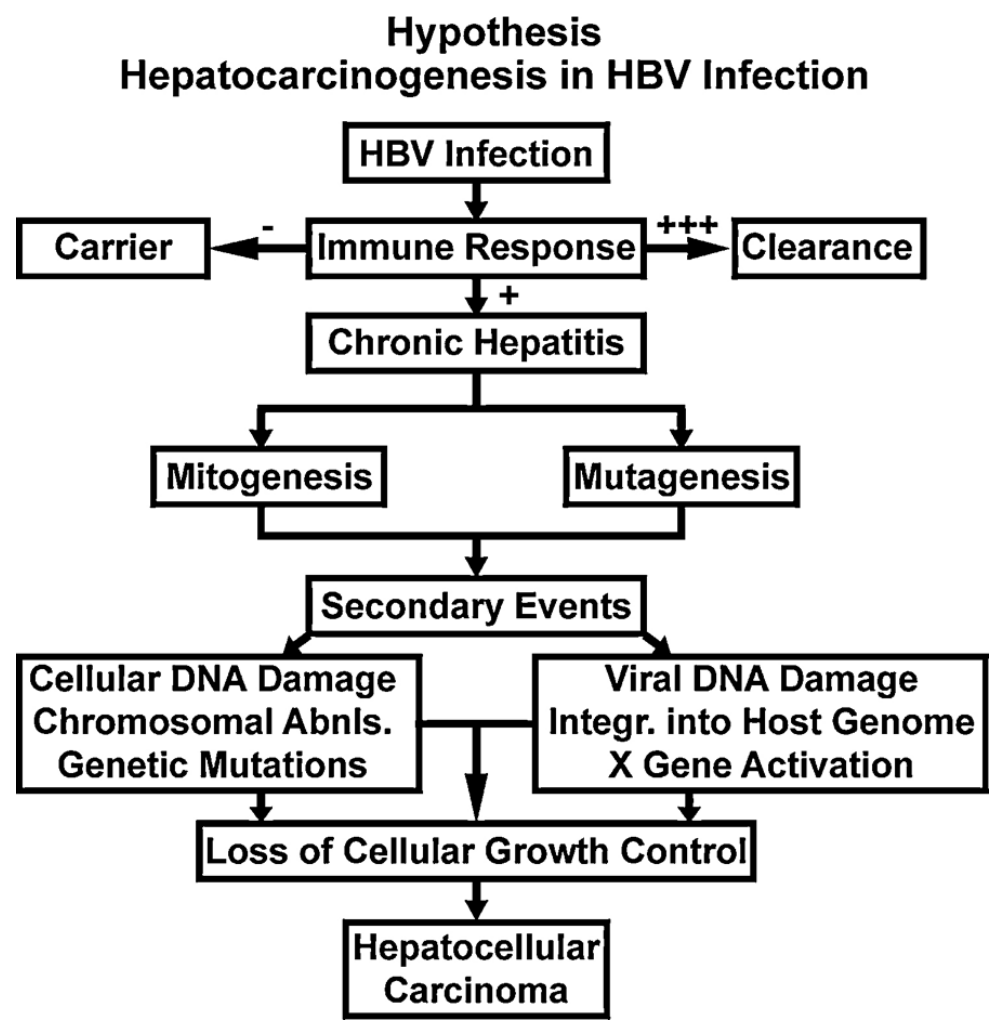

Figure 5.

The chronic injury $\rightarrow$ HCC hypothesis. According to this hypothesis, a vigorous $(+++)$ immune response to HBV leads to viral clearance while an absent $(-)$ immune response leads to the "healthy" carrier state, and an intermediate (+) immune response produces chronic hepatitis. This indolent necroinflammatory liver disease is characterized by chronic liver cell necrosis which stimulates a sustained regenerative response. The inflammatory component includes activated macrophages that are a rich source of free radicals. The collaboration of these mitogenic and mutagenic stimuli has the potential to cause cellular and viral DNA damage, chromosomal abnormalities, genetic mutations, etc, that deregulate cellular growth control in a multistep process that eventually leads to hepatocellular carcinoma. Reprinted from Am J Pathol 2000, 156:1117-1132 with permission from the American Society for Investigative Pathology. 